\title{
MOŻLIWOŚCI WYKORZYSTANIA POPIOLÓW WYSOKOWAPNIOWYCH DO OTRZYMYWANIA ZAPRAW TYNKARSKICH
}

\begin{abstract}
W artykule przeanalizowano możliwość stosowania popiołów lotnych z Elektrowni Pątnów do otrzymania zapraw tynkarskich Ze względu na zmienny skład chemiczny tych popiołów utylizacja tego typu surowca jest trudna. W trakcie przeprowadzonych badań napotkano problem wzrostu objętości wywołany zbyt szybkim wiązaniem anhydrytu oraz krystalizacją wodorotlenku magnezu. Konsekwencją tych procesów jest niszczenie stwardniałej zaprawy. Badaniom poddano właściwości reologiczne oraz podstawowe parametry stwardniałej zaprawy. Wykonane badania wybranych właściwości zapraw, wskazują, że popiół lotny może być wykorzystany do otrzymania zapraw tynkarskich i murarskich.
\end{abstract}

Słowa kluczowe: popiół lotny, pucolana, peryklaz, tlenek wapnia

\section{Wstęp}

Popiół lotny towarzyszy spoiwom mineralnym od tysięcy lat i w znaczny sposób może modyfikować właściwości użytkowe spoiw. Jest wartościowym dodatkiem mineralnym stosowanym w wielu gałęziach przemysłu. Świadome wprowadzenie popiołu do spoiw mineralnych święciło triumfy już w starożytnym Rzymie, aby nadać zaprawom wapiennym cechy materiałów wiążących, jako dodatek wprowadzano popioły wulkaniczne. Rozwój energetyki spowodował pojawienie się dużej ilości popiołów o właściwościach pucolanowych, a często także hydraulicznych. Znalazły one zastosowanie jako składnik cementu oraz dodatek do betonu $[4,8]$.

W Polsce popioły lotne wapniowe powstają głównie ze spalania węgla brunatnego w Elektrowni Bełchatów oraz na terenie okręgu konińskiego (Pątnów, Adamów, Konin). Tego typu popioły mają bardziej złożony skład mineralny aniżeli popioły lotne krzemionkowe. Odnosi się to zarówno do składników krystalicznych, jak i fazy szklistej[2].

\footnotetext{
${ }^{1}$ Autor do korespondencji: Wioleta Iskra - Kozak, Politechnika Rzeszowska, al. Powstańców Warszawy 12, 35-959 Rzeszów, tel. 17 8651701,w_iskra@prz.edu.pl
} 
Poszczególne frakcje ziarnowe tych popiołów mają zróżnicowany skład chemiczny i mineralny. $\mathrm{CaO}$ najczęściej występuje w trzech składnikach: w anhydrycie, w postaci wolnej i w fazie szklistej. Najczęściej najdrobniejsza frakcja ziarnowa jest najbogatsza w związki wapnia, zatem powinna wykazywać najlepsze właściwości hydrauliczne [5].

Czas wiązania tych popiołów mieści się w granicach od kilku minut do nawet kilkunastu godzin, a stwardniały zaczyn popiołowy może osiągać wytrzymałości na ściskanie nawet do $30 \mathrm{MPa}$.

Ze względu na zbyt dużą zawartość wolnego $\mathrm{CaO}$ czy $\mathrm{MgO}$ oraz stosunkowo małą aktywność hydrauliczną, popioły te nie cieszą się dużym powodzeniem wśród producentów materiałów budowlanych $[1,3]$.

$\mathrm{W}$ przypadku zbyt wysokiej zawartości wolnego $\mathrm{CaO}$ zaprawa popiołowa w początkowym okresie wykazuje znaczną wytrzymałość, po czym następuje spadek wytrzymałości. Dzieje się tak ze względu na opóźnioną hydratację $\mathrm{CaO}$. Wapno wypalone w wysokiej temperaturze hydratyzuje powoli, a podczas tego procesu następuje zmiana objętości, bo może prowadzić do zniszczenia zaczynu popiołowego [9].

Kolejnym problemem jest wzrost objętości spowodowany krystalizacją wodorotlenku magnezu. Proces ten wywołuje naprężenia rozciągające w stwardniałym zaczynie, co prowadzi do powstania mikrospęknięć. Takie zaprawy wykazują dużą nasiąkliwość, niską mrozoodporność, a co za tym idzie wysoki spadek wytrzymałości [9].

\section{Materiały i metody badań}

Wykorzystane w badaniach popioły lotne charakteryzowały się zróżnicowanym składem chemicznym. W tabelach poniżej przedstawiono skład popiołu lotnego niefrakcjonowanego (tab. 1) oraz popiołu lotnego rozdzielonego na frakcje przez separację pneumatyczną (tab. 2).

Mieszanki zostały przygotowane zgodnie z PN-EN 1015-2:1998. Przed przygotowaniem receptur przeprowadzono badania wstępne na recepturach próbnych.

Pierwszym problemem jaki się pojawił podczas badań był wzrost objętości próbek, wywołany zbyt szybkim wiązaniem gipsu, przez co wapno nie mogło w plastycznej matrycy w pełni hydratyzować [7]. Aby temu zjawisku zapobiec, dodano klinkier portlandzki (jako regulator czasu wiązania) w ilości odpowiednio 5\% i $10 \%$. Dodatkowo zastosowano kwas cytrynowy w celu opóźnienia czasu wiązania gipsu. Zawartość opóźniacza wyniósł około $0,5 \%$ masy gipsu. Jako kruszywo drobne zastosowano piasek o wielkości ziaren do $1 \mathrm{~mm}$, odmiany 2 [14]. 
Możliwości wykorzystania popiołów wysokowapniowych...

Tablica 1. Skład chemiczny popiołu lotnego z Elektrowni Pątnów niefrakcjonowanego

Table 1. Chemical composition of the unfactionally fly ash from the Pątnów Power Station

\begin{tabular}{|l|c|c|c|c|c|c|}
\hline KOD & K-001/F1 & K-001/F2 & K-001/F3 & K-001/F4 & K-001/F5 & K-001/F6 \\
\hline Frakcja & $0-15 \mu \mathrm{m}$ & $\begin{array}{c}15-30 \\
\mu \mathrm{m}\end{array}$ & $\begin{array}{c}30-45 \\
\mu \mathrm{m}\end{array}$ & $\begin{array}{c}45-63 \\
\mu \mathrm{m}\end{array}$ & $63-100 \mu \mathrm{m}$ & $\begin{array}{c}100-1000 \\
\mu \mathrm{m}\end{array}$ \\
\hline Zawartość & \multicolumn{7}{|c|}{$\%$} \\
\hline Strata prażenia & 1,266 & 0,378 & 0,224 & 0,207 & 0,617 & 0,041 \\
\hline $\mathrm{SiO}_{2}$ & 13,833 & 21,665 & 30,944 & 44,675 & 64,556 & 88,87 \\
\hline $\mathrm{Al}_{2} \mathrm{O}_{3}$ & 7,002 & 7,837 & 8,375 & 8,988 & 7,986 & 1,827 \\
\hline $\mathrm{Fe}_{2} \mathrm{O}_{3}$ & 3,467 & 5,518 & 8,729 & 10,059 & 9,116 & 5,971 \\
\hline $\mathrm{CaO}$ & 48,295 & 46,038 & 37,524 & 25,441 & 11,552 & 2,077 \\
\hline $\mathrm{MgO}$ & 6,661 & 6,407 & 5,309 & 3,777 & 1,954 & 0,353 \\
\hline $\mathrm{SO}_{3}$ & 16,812 & 9,583 & 6,182 & 4,157 & 2,003 & 0,339 \\
\hline $\mathrm{K}_{2} \mathrm{O}$ & 0,347 & 0,326 & 0,569 & 0,832 & 0,927 & 0,215 \\
\hline $\mathrm{Na}_{2} \mathrm{O}$ & 0,189 & 0,126 & 0,127 & 0,138 & 0,128 & 0,035 \\
\hline $\mathrm{CaO}_{\text {reaktywne }}$ & 35,82 & 38,86 & 32,93 & 22,48 & 10,14 & 1,84 \\
\hline $\mathrm{CaO}_{\text {wolne }}$ & 13,56 & 16,77 & 13,46 & 7,34 & 3,39 & 1,73 \\
\hline
\end{tabular}

Tablica 2. Skład chemiczny popiołu lotnego z Elektrowni Pątnów po separacji

Table 2. Chemical composition of the fly ash from the Pątnów Power Station after the separation

\begin{tabular}{|l|l|}
\hline $\mathrm{KOD}$ & K-001 \\
\hline Frakcja & \\
\hline Zawartość & $\%$ \\
\hline Strata prażenia & 0,784 \\
\hline $\mathrm{SiO}_{2}$ & 50,754 \\
\hline $\mathrm{Al}_{2} \mathrm{O}_{3}$ & 6,091 \\
\hline $\mathrm{Fe}_{2} \mathrm{O}_{3}$ & 5,968 \\
\hline $\mathrm{CaO}$ & 24,757 \\
\hline $\mathrm{MgO}$ & 3,571 \\
\hline $\mathrm{SO}$ & 6,185 \\
\hline $\mathrm{K}_{2} \mathrm{O}$ & 0,460 \\
\hline $\mathrm{Na}_{2} \mathrm{O}$ & 0,107 \\
\hline $\mathrm{CaO}_{\text {reaktywne }}$ & 20,12 \\
\hline $\mathrm{CaO}_{\text {wolne }}$ & 7,15 \\
\hline
\end{tabular}


Po wykonaniu badań wstępnych sporządzono 4 receptury o składach przedstawionych $\mathrm{w}$ tabeli 3 .

Tablica 3. Receptury badanych zapraw

Table 3. Formula of the examined mortars

\begin{tabular}{|c|c|c|c|c|c|c|}
\hline \multirow{2}{*}{ O气 } & \multicolumn{5}{|c|}{ Skład zaprawy [\%] } & \multirow{2}{*}{$\begin{array}{c}\begin{array}{c}\text { Zawartość w sto- } \\
\text { sunku do spoiwa } \\
{[\%]}\end{array} \\
\begin{array}{c}\text { Kwas cytrynowy } \\
\text { Kwo }\end{array}\end{array}$} \\
\hline & $\begin{array}{l}\text { Popiół } \\
\text { K001 }\end{array}$ & $\begin{array}{l}\text { Popiół } \\
\text { (F1+F2) }\end{array}$ & $\begin{array}{c}\text { Popiół } \\
\text { (F3+F4+F5) }\end{array}$ & $\begin{array}{c}\text { Klinkier por- } \\
\text { tlandzki }\end{array}$ & $\begin{array}{l}\text { Piasek } \\
\text { do } 1 \mathrm{~mm}\end{array}$ & \\
\hline IW-1 & 52 & & - & 10 & 38 & 0,5 \\
\hline IW-2 & 39 & & - & 5 & 56 & 0,5 \\
\hline IW-3 & - & 34 & 18 & 10 & 38 & 0,5 \\
\hline IW-4 & - & 26 & 13 & 5 & 56 & 0,5 \\
\hline IW-5 & 52 & & - & 10 & 38 & 0,5 \\
\hline
\end{tabular}

W trakcie pierwszych 7 dni dojrzewania próbek, zauważono, że próbki ponownie zwiększają swoją objętość. Problem ten głównie dotyczył zapraw, które w swoim składzie zawierały popioły lotne o grubszej frakcji (popiół K001 oraz popiół o frakcji F6). Analizując skład stwierdzono, że problem wynika z obecności dużych ziaren peryklazu, znajdujących się we frakcji F6 oraz w popiele lotnym K001. W celu wyeliminowania tego problemu odrzucono frakcję F6, a popió1 K001 (zaprawa IW-1) poddano zmieleniu. Po zmieleniu popiół lotny poddano oznaczeniu miałkości przez przesiewanie na mokro na sicie $0,045 \mathrm{~mm}$, zgodnie z PN-EN 451-2:1998, a następnie sporządzono zaprawę o składzie IW-5 [13].

W celu określenia właściwości reologicznych zapraw wykonano następujące badania:

a) konsystencji metodą stożka pomiarowego według PN-B-04500:1985 oraz stolika rozpływu według PN-EN 1015-3:2000 [10, 12].

b) czasu zachowania właściwości roboczych według PN-EN 1015-9:1999 [13].

Przeprowadzono również badania stwardniałych zapraw:

a) wytrzymałości na zginanie i ściskanie po 7 i 28 dniach dojrzewania stosując próbkę o wymiarach 40x40x160 mm według PN-EN 1015-11:2001 [14].

b) zmian liniowych po 7 i 28 dniach dojrzewania za pomocą aparatu GrafKaufmana na beleczkach z czopami o wymiarach 40x40x160 mm według PN-B-04500:1985 [10].

c) nasiąkliwości po 28 dniach dojrzewania na próbkach o wymiarach 40x40x160 mm według PN-B-04500:1985 [10].

d) przyczepności do podłoża po 28 dniach dojrzewania na krążkach o średnicy 50 mm według PN-EN 1015-12:2002 [15]. 
Dodatkowo przeprowadzono obserwacje mikroskopowe SEM wraz z analizą EDS stosowanych popiołów lotnych.

\section{Omówienie wyników badań}

\subsection{Konsystencja}

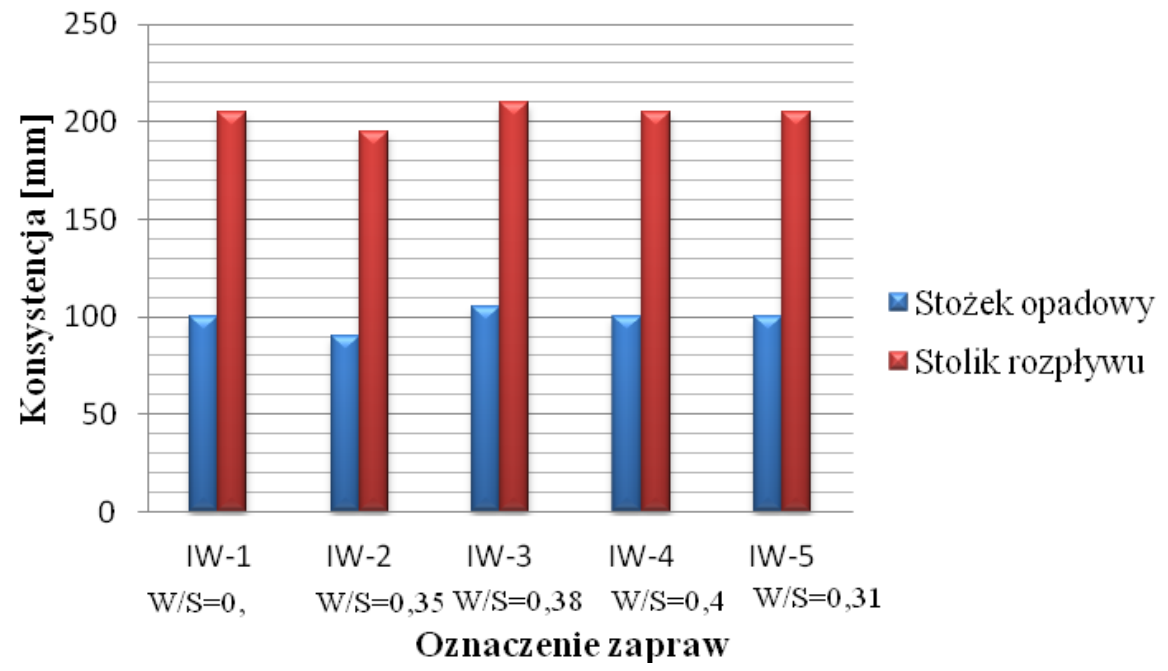

Rys. 1 . Konsystencja zapraw badana metodą stożka pomiarowego i stolika rozpływu

Fig. 1. Consistency of mortars examined with method of the measuring cone and the table of the syneresis

$\mathrm{Z}$ analizy wyników konsystencji badanej metodą stożka pomiarowego i stolika rozpływu można zauważyć, że wyniki wszystkich badanych zapraw są porównywalne. Dążono do uzyskania głębokości zanurzenia stożka w granicach $10-11 \mathrm{~cm}$, ponieważ przewiduje się, że zaprawa będzie podawana mechanicznie [6]. Podczas badania metodą stolika rozpływu dążono do uzyskania rozpływu w granicach $20-21 \mathrm{~cm}$. Stosunek w/s poszczególnych zapraw jest zmienny. $\mathrm{Z}$ uzyskanych wyników wynika, że najwyższe wartości w obu badaniach wykazały zaprawy IW-3, IW-4 i IW-5, zawierające frakcję drobną. Wodożądność wzrasta wraz z wzrostem zawartości frakcji F1 i F2.

\subsection{Czas zachowania właściwości roboczych}

Z analizy czasu zachowania właściwości roboczych badanych zapraw (Rys. 2) wynika, że najdłużej właściwości robocze wykazują zaprawy IW-1, IW-3 i IW-5. Czas ten wydłuża się do prawie $170 \mathrm{~min}$, czyli o $20 \% \mathrm{w}$ porównaniu z zaprawami IW-2 i IW-4. Warto zwrócić uwagę, że ilość dodawanego kwasu cytrynowego pozostała stała. Wydłużenie czasu wynika z zawartości 
klinkieru portlandzkiego w poszczególnych zaprawach. Im wyższa jego zawartość w zaprawie (w tym przypadku 10\%) tym czas zachowania właściwości roboczych większy. Wynika to prawdopodobnie z zawartości gipsu w popiołach będącego źródłem jonów siarczanowych (klinkier konsumuje gips). Na powierzchni ziaren glinianu trójwapniowego tworzy się cienka warstewka, nieprzepuszczalnego dla wody ettringitu - uwodnionego siarczanoglinianu wapnia, który hamuje postęp hydratacji $\mathrm{C}_{3} \mathrm{~A}$ zapobiegając błyskawicznemu wiązaniu, przez co czas zachowania właściwości roboczych wydłuża się [7]. Dodatkowo czas zostaje wydłużony poprzez $0,5 \%$ dodatek kwasu cytrynowego.

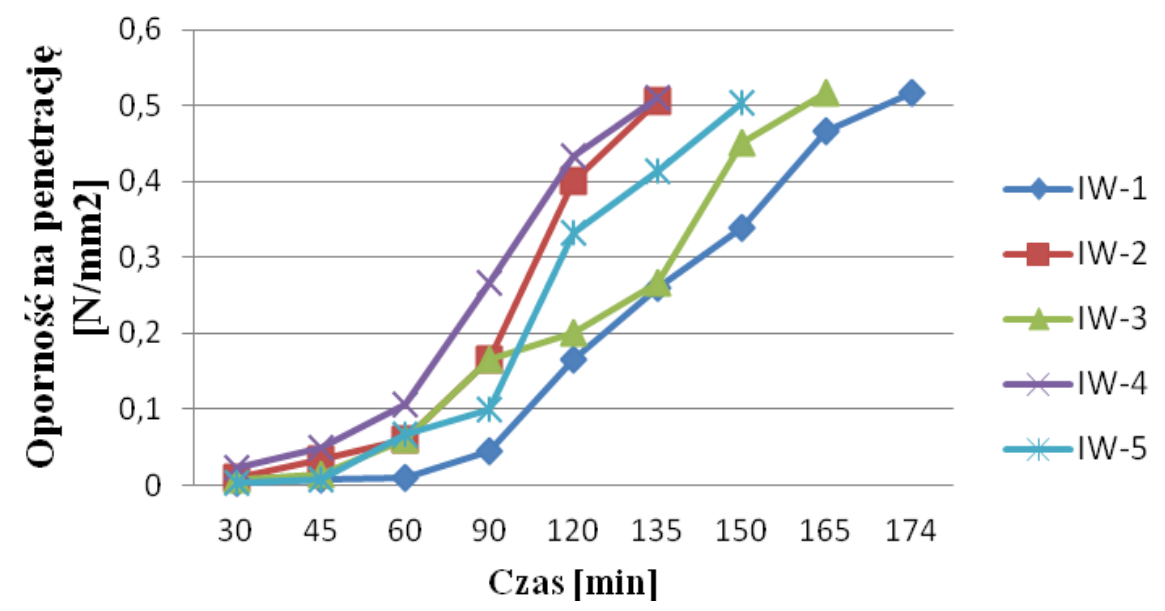

Rys. 2. Czas zachowania właściwości roboczych poszczególnych zapraw

Fig. 2. Time of keeping the property of working individual mortars

\subsection{Wytrzymałość na zginanie i ściskanie}

Tablica 4. Wyniki badań wytrzymałości na zginanie i ściskanie po 7 i 28 dniach dojrzewania zapraw

Table 4. Test results of the bending and compression strength after 7 and 28 days for ripening of mortars

\begin{tabular}{|c|c|c|c|c|c|c|c|c|c|c|}
\hline \multicolumn{10}{|c|}{ Wytrzymalość na zginanie i ściskanie $\pm \delta$ [MPa] } \\
\hline $\begin{array}{c}\text { Okres } \\
\text { (dni) }\end{array}$ & \multicolumn{2}{|c|}{$\mathrm{IW}-1$} & \multicolumn{2}{|c|}{$\mathrm{IW}-2$} & \multicolumn{2}{|c|}{$\mathrm{IW}-3$} & \multicolumn{2}{|c|}{$\mathrm{IW}-4$} & \multicolumn{2}{|c|}{$\mathrm{IW}-5$} \\
\hline & $\mathrm{R}_{\mathrm{f}}$ & $\mathrm{R}_{\mathrm{c}}$ & $\mathrm{R}_{\mathrm{f}}$ & $\mathrm{R}_{\mathrm{c}}$ & $\mathrm{R}_{\mathrm{f}}$ & $\mathrm{R}_{\mathrm{c}}$ & $\mathrm{R}_{\mathrm{f}}$ & $\mathrm{R}_{\mathrm{c}}$ & $\mathrm{R}_{\mathrm{f}}$ & $\mathrm{R}_{\mathrm{c}}$ \\
\hline \multirow{2}{*}{7} & 0,74 & 1,38 & 0,65 & 1,13 & 0,59 & 1,41 & 1,01 & 2,78 & 2,00 & 9,38 \\
& $\pm 0,02$ & $\pm 0,01$ & $\pm 0,09$ & $\pm 0,08$ & $\pm 0,02$ & $\pm 0,07$ & $\pm 0,05$ & $\pm 0,11$ & $\pm 0,43$ & $\pm 0,51$ \\
\hline \multirow{2}{*}{28} & 5,11 & 19,57 & 1,32 & 6,69 & 2,61 & 9,88 & 2,30 & 10,40 & 5,18 & 15,33 \\
& $\pm 0,44$ & $\pm 0,41$ & $\pm 0,17$ & $\pm 0,26$ & $\pm 0,08$ & $\pm 0,11$ & $\pm 0,19$ & $\pm 0,06$ & $\pm 0,15$ & $\pm 0,12$ \\
\hline
\end{tabular}

$\mathrm{R}_{\mathrm{f}}-$ wytrzymałość na zginanie

$\mathrm{R}_{\mathrm{c}}$ - wytrzymałość na ściskanie 
Analizując wyniki badań wytrzymałości na zginanie i ściskanie (tab. 4) można dostrzec, że najwyższe wytrzymałości otrzymano dla zapraw IW-1 i IW-5. Wyniki uzyskane dla tych zapraw są porównywalne. Najniższą wytrzymałość na zginanie i ściskanie otrzymano dla zaprawy IW-2.

Zgodnie z PN-EN 1015-11:2001 i PN-EN 998-2:2003 zaklasyfikowano badane zaprawy w zależności od wytrzymałości na ściskanie według poszczególnych klas (tab. 5, tab. 6).

Tablica 5. Klasyfikacja badanych zapraw zgodnie z PN-EN 1015-11:2001

Table 5. Classification of examined mortars according to PN-EN 1015-11: 2001

\begin{tabular}{|c|c|}
\hline Oznaczenie & Klasa \\
\hline IW-1 & CS IV \\
\hline IW-2 & CS III \\
\hline IW-3 & CS IV \\
\hline IW-4 & CS IV \\
\hline IW-5 & CS IV \\
\hline
\end{tabular}

Tablica 6. Klasyfikacja badanych zapraw zgodnie z PN-EN 998-2:2003

Table 6. Classification of examined mortars according to PN-EN 998-3: 2003

\begin{tabular}{|c|c|}
\hline Oznaczenie & Klasa \\
\hline IW-1 & M 15 \\
\hline IW-2 & M 5 \\
\hline IW-3 & M 5 \\
\hline IW-4 & M 10 \\
\hline IW-5 & M 15 \\
\hline
\end{tabular}

\subsection{Nasiąkliwość}

Na podstawie wyników badań nasiąkliwości (Tab. 7) stwierdzono, że zaprawa IW-2 charakteryzuje się najwyższą nasiąkliwością. W porównaniu z pozostałymi wariantami zapraw (IW-1, IW-3, IW-4, IW-5) jest większa o około 40\% i będzie prawdopodobnie wykazywała najniższą mrozoodporność. Najniższą nasiąkliwość wykazują zaprawy IW-3 oraz IW-4, odpowiednio 12\% i 12,8\%. 
Tablica 7. Nasiąkliwość zapraw w stosunku do masy w \%

Table 7. Absorbability of the mortars in the relations to mass in $\%$

\begin{tabular}{|c|c|c|c|c|}
\hline \multicolumn{5}{|c|}{ Nasiąkliwość zapraw w stosunku do masy, [\%] } \\
\hline IW-1 & IW-2 & IW-3 & IW-4 & IW-5 \\
\hline $17,5 \pm 0,03$ & $23,2 \pm 0,12$ & $12,0 \pm 0,04$ & $12,8 \pm 0,16$ & $15,5 \pm 0,01$ \\
\hline
\end{tabular}

\subsection{Zmiany liniowe $w$ okresie twardnienia}

Interpretując wyniki za pomocą zmian liniowych wszystkich zapraw można stwierdzić, że wszystkie badane próbki zwiększyły swoją objętość (Tab. 8). Największe zmiany liniowe wykazały zaprawy IW-1 oraz IW-2, prawdopodobnie wskutek wzrostu objętości dużych ziaren peryklazu zawartych w popiele lotnym K001. W związku z tym, popiół lotny K001 (wariant IW-1) poddano zmieleniu, co spowodowało znaczny spadek objętości (wariant IW-5, spadek o 90\%).

Najmniejsze zmiany liniowe wykazały zaprawy IW-3 i IW-4. Mimo, iż popiół lotny o drobnej frakcji (F1-F5) podczas analizy wykazywał niewielkie ilości peryklazu to nie okazał się on szkodliwy ( prawdopodobnie ze względu na niewielki rozmiar jego ziaren).

Tablica 8. Zmiany liniowe w okresie 7 i 28 dni dojrzewania

Table 8 . Linear changes in period 7 and 28 days of ripening

\begin{tabular}{|c|c|c|c|c|c|}
\hline \multicolumn{7}{|c|}{ Skurcz w okresie twardnienia [\%] } \\
\hline Okres (dni) & IW-1 & IW-2 & IW-3 & IW-4 & IW-5 \\
\hline 7 & $-1,64 \pm 0,02$ & $-1,02 \pm 0,35$ & $-0,46 \pm 0,21$ & $-0,07 \pm 0,02$ & $-0,21 \pm 0,02$ \\
\hline 28 & $-2,24 \pm 0,11$ & $-4,67 \pm 0,28$ & $-0,97 \pm 0,14$ & $-0,14 \pm 0,04$ & $-0,23 \pm 0,06$ \\
\hline
\end{tabular}

\subsection{Przyczepność do podłoża}

Największą przyczepność do podłoża (tab. 9) wykazały zaprawy IW-4 i IW-5. Wyniki badań przyczepności tych dwóch zapraw są porównywalne i wynoszą około 2,25 MPa. Zaprawy IW-1 i IW-3 wykazały o około 50\% niższą przyczepność, natomiast zaprawa IW-2 o prawie $80 \%$ w stosunku do zapraw IW-4 i IW-5.

Tablica 9. Przyczepność do podłoża badanych zapraw tynkarskich

Table 9. Adhesion of examined masonry mortars to base

\begin{tabular}{|c|c|c|c|c|}
\hline \multicolumn{5}{|c|}{ Przyczepność do podłoża [N/mm $]$} \\
\hline IW-1 & IW-2 & IW-3 & IW-4 & IW-5 \\
\hline $1,37 \pm 0,08$ & $0,5 \pm 0,02$ & $1,05 \pm 0,03$ & $2,28 \pm 0,07$ & $2,23 \pm 0,02$ \\
\hline
\end{tabular}


Modele pęknięcia do których doszło podczas badania przedstawiono na rysunkach poniżej (Rys.3). W zaprawach IW-4 i IW-5 nastąpiło pęknięcie kohezyjne w samej zaprawie. W przypadku pozostałych zaprawa IW-1, IW-2 IW-3 nastąpiło pęknięcie adhezyjne na styku zaprawy z podłożem [6].

a)

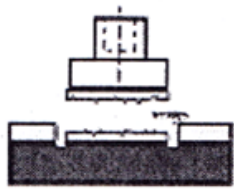

Rys. 3. a) Pęknięcie kohezyjne w samej zaprawie b) Pęknięcie adhezyjne na styku zaprawy $\mathrm{z}$ podłożem.

Fig. 3. a) Cohesion crack inside mortar b) Adhesion crack on the joint of mortar with base

W analizie SEM oraz jakościowej i ilościowej analizie rozkładu pierwiastków w badanych próbkach stwierdzono, że główną fazą jest siarczan wapnia $\mathrm{CaSO}_{4}$. W popiele lotnym występują śladowe ilości glinu, żelaza oraz węgla. Szczególną uwagę zwraca pojawiający się tlenek magnezu, który spowodował wzrost objętości próbek zaprawy (Rys. 4). Dokonana analiza wykazała obecność żelaza. Zbyt wysoka jego zawartość w stwardniałej mieszance betonowej może doprowadzić do wystąpienia plam na jej powierzchni [7]. Stwierdzono śladowe ilości chloru, glinu oraz sodu (Rys. 5).
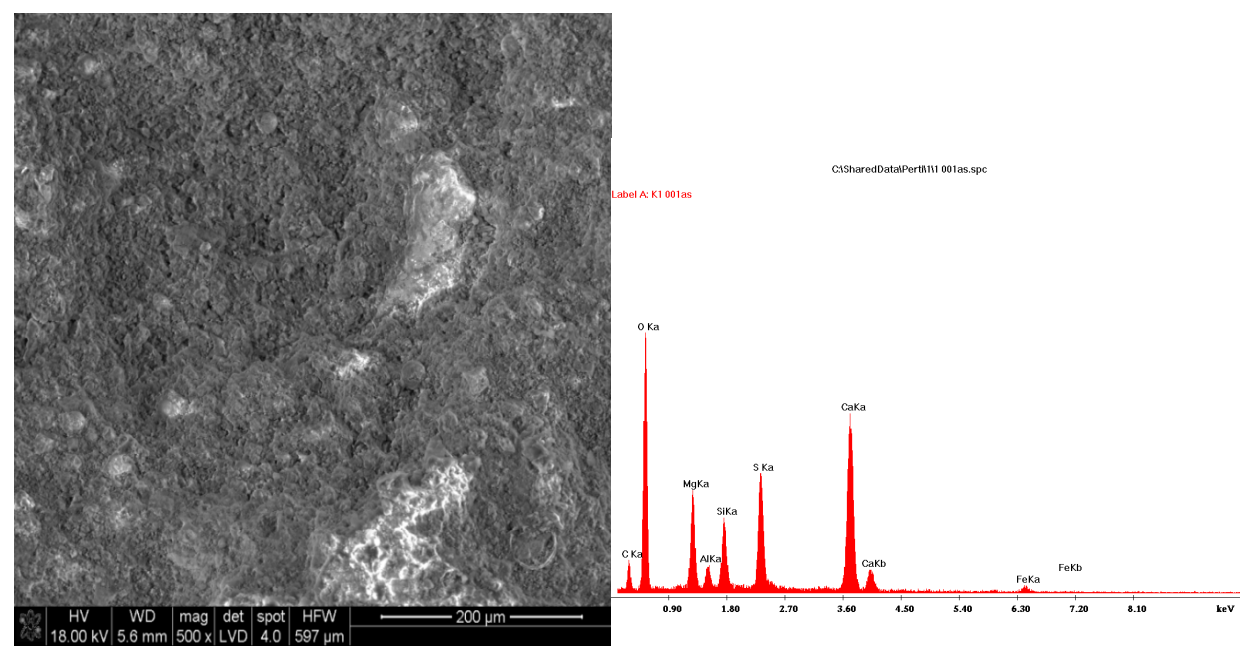

Rys. 4. Obraz SEM z analizą powierzchniową EDS popiołu lotnego siarczanowo-wapniowego z Elektrowni Pątnów

Fig. 4. SEM image with EDS surface analysis of the sulphate - calcium fly ash from the Pątnów Power Station 


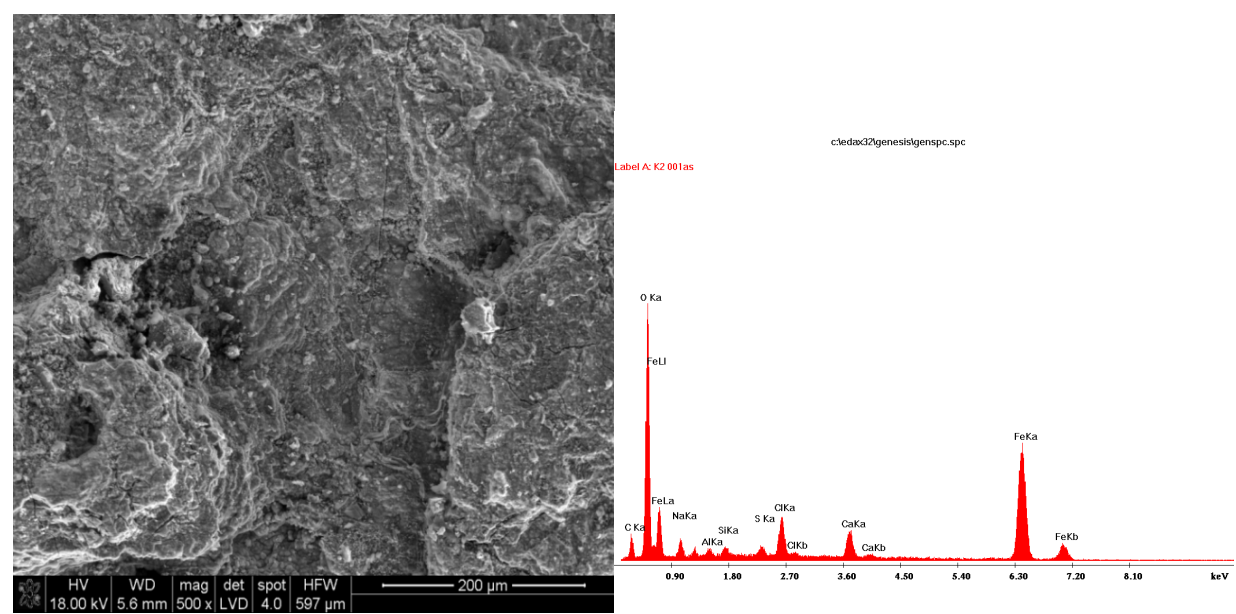

Rys. 5. Obraz SEM z analizą powierzchniową EDS popiołu lotnego siarczanowo-wapniowego z Elektrowni Pątnów

Fig. 5. SEM image with EDS surface analysis of the sulphate - calcium fly ash from the Pątnów Power Station

\section{Wnioski}

W pracy przedstawiono wyniki badań, mających na celu utylizację popiołu lotnego siarczanowo-wapniowego pochodzącego z Elektrowni Pątnów, wskutek zastosowania go do wykonania zapraw tynkarskich.

Z przeprowadzonych badań wypływają następujące wnioski:

1. Podjęta próba utylizacji popiołów lotnych siarczanowo-wapniowych z Elektrowni Pątnów poprzez zastosowanie ich do wykonania zapraw tynkarskich zakończyła się powodzeniem.

2. Przeprowadzone badania wykazały, że popiół lotny nadał zaprawom tynkarskim pożądane właściwości.

3. W celu zlikwidowania zakłóceń technologicznych polegających na pęcznieniu zapraw dodano klinkier portlandzki w celu opóźnienia czasu wiązania anhydrytu, tak aby tlenek wapnia mógł w pełni hydratyzować.

4. Występujące duże ziarna peryklazu stanowią problem, który można zlikwidować stosując wydzielone frakcje popiołu lotnego lub poddając popiół lotny zmieleniu.

5. Badane popioły mogą stanowić potencjalny składnik do otrzymywania zapraw murarskich. 


\section{Literatura}

[1] Baran T., Garbacik A.: Popioły wysokowapniowe szansą uzupełnienia bazy popiołów dla przemysłu cementowego, Instytut Ceramiki, Szkła, Materiałów Ogniotrwałych i Budowlanych, Oddział Mineralnych Materiałów Budowlanych, Kraków, 2010.

[2] Chudek M., Hycnar J., Plewa F.: Węgiel brunatny - utylizacja surowców towarzyszących i odpadów elektrownianych, Wydawnictwo Politechniki Śląskiej, Gliwice 1999.

[3] Giergiczny Z.: High calcium fly ash, Cement -Wapno - Beton, nr 5, 2005, 271-282.

[4] Giergiczny Z., Gawlicki M.: Popiół lotny jako aktywny składnik cementów i dodatek mineralny do betonu, Materiały z Konferencji Dni Betonu - Tradycja i Nowoczesność, s. 277-293, Wisła 2004.

[5] Giergiczny Z., Weryńska A.: Wpływ rozdrobnienia popiołu lotnego z węgla brunatnego na własności wytrzymałościowe spoiw cementowo-popiołowych, XXXIII Konferencja Naukowa Komitetu Inżynierii Lądowej i Wodnej PAN i Komitetu Nauki PZITB, Gliwice - Krynica 1987, t. 4.

[6] Małolepszy J. (red.): Materiały budowlane. Podstawy technologii i metody badań, AGH, Kraków 2008r.

[7] Neville A. M.: Właściwości betonu, Kraków 2000.

[8] Neya R.: Mineralne surowce odpadowe, Wydawnictwo Instytutu Gospodarki Surowcami Mineralnymi i Energią PAN, 2009.

[9] Pytel Z.: Technologia i właściwości autoklawizowanego materiału budowlanego z siarczanowo-wapniowych popiołów lotnych, Rozprawa doktorska, Akademia Górniczo-Hutnicza w Krakowie, Kraków, 1994.

[10] PN-B-04500:1985: Zaprawy budowlane. Badania cech fizycznych i wytrzymałościowych.

[11] PN-EN 451-2:1998: Metoda badania popiołu lotnego. Oznaczanie miałkości przez przesiewanie na mokro.

[12] PN-EN 1015-3:2000: Metody badań zapraw do murów. Określenie konsystencji świeżej zaprawy (za pomocą stolika rozpływu).

[13] PN-EN 1015-9:1999: Metody badań zapraw do murów Część 9: Określenie czasu zachowania właściwości roboczych i czasu korekty świeżej zaprawy.

[14] PN-EN 1015-11:2001: Metody badań zapraw do murów Część 11: Określenie wytrzymałości na zginanie i ściskanie stwardniałej zaprawy.

[15] PN-EN 1015-12:2002: Metody badań zapraw do murów Część 12: Określenie przyczepności do podłoża stwardniałych zapraw na obrzutkę i do tynkowania.

[16] PN-79/B-06711: Piaski do zapraw budowlanych. 


\title{
THE POSSIBILITIES OF USING HIGH-CALCIUM ASHES FOR OBTAINING MASONRY MORTARS
}

\begin{abstract}
S u m m a r y
In the article a possibility of applying fly ashes from Pątnów Power Station was analysed for obtaining masonry mortars. On account of the changeable chemical composition of these ashes the recycling of the raw material of this type is difficult. In the course of the conducted examination a problem of the volume increase triggered by too fast anhydrite setting and the crystallization of the magnesium hydroxide was encountered. A decay of hardened mortar is a consequence of these processes. Rheological properties and basic parameters of hardened mortar were tested. The performed research on the chosen properties of mortars shows that the fly ash can be used for obtaining masonry mortars and bricklaying.
\end{abstract}

Keywords: fly ash, puzzolan, periclase, calcium oxide

Przestano do redakcji:25.11.2014

Przyjęto do druku:1.12.2015

DOI: $10.7862 / \mathrm{rb} .2015 .146$ 